\title{
SIKAP DAN KEBIJAKSANAAN SOEKARNO TERHADAP ISLAM PASCA KEMERDEKAAN
}

\author{
Dr. Anwar Sanusi, M.Ag \\ Jurusan Sejarah Peradaban Islam IAIN Syekh Nurjati Cirebon
}

\section{Abstrak}

Soekarno menyeru umat Islam untuk "menggali api Islam",. Perdebatan mengenai bentuk negara antara nasionalis-sekuler dengan kelompok nasionalis-Islam membuat Soekarno berpikir untuk menemukan formulasi yang bisa diterima oleh semua kelompok, yakni Rumusan Pancasila sila pertama yaitu Ketuhanan Yang Maha Esa yang merupakan akumulasi perdebatan dua kelompok tersebut. Selain perdebatan tersebut, Soekarno juga menghadapi persoalan sistem parlementer yang mengalami jatuh bangun sehingga Soekarno menggagas Demokrasi Terpimpin. Di sisi lain, Soekarno juga menggagas konsep NASAKOM atau integrasi persoalan bangsa dari nasionalisme (PNI), agama (NU) dan sosialisme (PKI) dengan dukungan militer. Hal ini tentunya menarik untuk diteliti dan menjadi tulisan yang dapat memaparkan mengenai sikap dan kebijaksanaan Soekarno, utamanya mengenai bidang ideologi dan keagamaan dalam khazanah sejarah tanah air.

Kata kunci : Transformatif, Soekarno, Pancasila dan Nasakom

\section{A. Pendahuluan}

Kemerdekaan Indonesia pada tanggal 17 Agustus 1945 membawa periode dan babak baru bagi bangsa Indonesia. Dalam rentang sejarah tersebut, para penggaggas NKRI berjibaku guna membenahi stabilitas yang ada guna membentuk suatu negara yang berdaulat pasca Indonesia memproklamirkan kemerdekaannya. Kita telah ketahui sebelumnya, bahwa sebelum rentang masa tersebut dibentuklah badan penyelidik untuk persiapan kemerdekaan Indonesia (BPUPKI) guna menyiapkan segala 
macam proses yang berhubungan dengan kemerdekaan NKRI, dan setelah kemerdekaan mulai dibentuklah asas bagi dasar sebuah negara untuk dapat menjalankan tata kehidupan bernegara yang baik dan sesuai dengan konsepsi para founding fathers yang telah berjuang mendirikan NKRI. Dalam prosesnya, pembentukan dasar negara ini memerlukan suatu konsep yang matang mengingat Indonesia yang baru merdeka memiliki berbagai macam keragaman, baik dalam konsep budaya, religi, maupun sosial yang tidak bisa dipisahkan. ${ }^{1}$

Dalam pembentukan dasar negara ini melibatkan berbagai elemen masyarakat termasuk dalam hal ini unsur umat Islam yang tidak dapat dipungkiri banyak terlibat didalam kepengurusan dan pemrosesan usulan dasar negara tersebut. Piagam Jakarta merupakan momentum dimana umat Islam mempunyai peranan besar didalamnya, namun setelahnya di akhir pembentukan daripada dasar negara yang tidak memasukkan piagam Jakarta kedalamnya banyak menimbulkan kekecewaan dipihak umat Islam. Kekecewaan ini semakin berkecamuk tatkala pada masa selanjutnya umat Islam juga tidak memiliki kemerdekaan dalam menyalurkan aspirasi politik. Soekarno, yang kala itu menjadi presiden pertama NKRI, hanya mengijinkan Masyumi sebagai satu-satunya wadah perpolitikan bagi umat Islam untuk maju ke pentas nasional. Masyumi sendiri berdasarkan pada banyak organisasi massa Islam dari berbagai macam latar belakang sehingga kurang dapat mewadahi keinginan semua pihak yang berada didalamnya. $^{2}$

Banyak kalangan yang menilai, utamanya dari unsur Islam yang menilai bahwa Soekarno dalam kebijakan-kebijakan yang diambilnya tidak

1 Endang Saifuddin Anshari,. Piagam Jakarta 22 Juni 1945 ; dan Sejarah Konsesnsus Nasional Antara Nasionalis Islam dan Nasionalis Sekuler Tentang Dasar Negara RI 19451959, Jakarta : CV Rajawali Press : 1986, hlm. 133.

2 Ibid., hlm. 134. 
berpihak kepada kelompok Islam. Hal ini sendiri tentunya menimbulkan kekecewaan tersendiri, mengingat banyaknya peranan umat Islam didalam masa perjuangan menuju kemerdekaan. ${ }^{3}$

Dalam konteks tertentu, Herbert Feith dan Lance Castles dalam bukunya yang terkenal yakni pemikiran politik di Indonesia pada masa pasca kemerdekaan ${ }^{4}$ membagi rentang sejarah politik di Indonesia menjadi tiga (3) bagian, yakni yang pertama adalah periode revolusi bersenjata (1945-1949). Pada periode sejarah ini, pemikiran politik yang ada diprakarsai oleh orang-orang terdidik pribumi yang kemudian mempunyai peranan penting dalam konteks pergerakan nasional kemerdekaan di Indonesia. Tokoh-tokohnya antara lain ialah Soekarno, Hatta, Syahrir, Tan Malaka, dan Natsir. Pada rentang sejarah ini, pencarian akan dasar negara menjadi isu pokok yang menjadi persoalan bagi Indonesia yang harus segera disolusikan. Dalam hal ini, hasil luaran daripada proses pemikiran tersebut salah satunya adalah Pancasila. ${ }^{5}$

Periode kedua, "liberal" (1950-1959) pemikiran politik mulai meluas, dalam hal ini para pemimpin negara dan juga para intelektul, seperti para penulis, sastrawan, wartawan, dan mahasiswa giat untuk melakukan diskusi-diskusi serta konsepsi mengenai politik pada masa tersebut. Masa ini juga ditandai oleh konflik yang disebabkan oleh perbedaan aliran politik dan kepartaian serta pertentangan ideologi yang ekstrim antara satu dan lainnya. Karena cukup terbukanya masa tersebut, maka masa ini juga disebut sebagai masa demokrasi parlementer.

3 Herbert Feith dan Lance Castles. Ed. Pemikiran Politik Indonesia 1945-1965, Jakarta : LP3ES ; 1988, hlm. 153.

4 Ibid., hlm. 155.

5 Herbert Feith, The Decline of Constitutional Democracy in Indonesia (1962), hlm. 195. 
Periode ketiga, dimana masa tersebut juga disebut periode masa demokrasi terpimpin (1959-1965), banyak dilalui oleh serentetan pembredelan media massa dan organisasi politik yang dianggap tidak sehaluan oleh presiden yang ada pada saat itu. Masa ini juga ditandai dengan penerimaan besar-besaran sebagian besar masyarakat terhadap ideide politik yang dikeluarkan oleh presiden Soekarno kala itu seperti Sosialisme ala Indonesia dan jargon Nasakom (Nasionalisme, Agama, Komunisme). ${ }^{6}$

Oleh Karena itu, apabila kita tilik lebih jauh pada masa tersebut, pemerintahan Soekarno terus melakukan himbauan dengan berulang-ulang yang mendominasi, dan hampir memonopoli diskusi publik. Tidak hanya itu, pemikir yang tidak sepaham dengan ide-ide itu dibungkam untuk melancarkan ide-ide politik yang berlawanan dengan Soekarno. Kondisi ini menjelaskan kalau pemerintah alergi dengan kritik atau oposisi.

\section{B. Kebijakan Soekarno Pada Masa Demokrasi Parlementer}

Dalam sistem parlementer, Presiden berkedudukan sebagai Kepala Negara dan kekuasaan yang dimiliki oleh Presiden ini tidak dapat diganggu gugat. Kekuasaan pemerintahan dipegang oleh Perdana Menteri, yang bertanggung jawab terhadap parlemen. Setiap kabinet yang berkuasa harus mendapat dukungan dari parlemen. Apabila 40 mayoritas suara yang ada dalam parlemen tidak mendukung kabinet, maka kabinet harus mengembalikan mandatnya kepada Presiden. Selain itu, parlemen dapat membubarkan kabinet sewaktu-waktu dengan suara mayoritas, namun

6 Ir. Soekarno. 1964. "Nasionalisme, Islamisme dan Marxisme", dalam Dibawah Bendera Revolusi, Jakarta: Departemen Penerangan, hlm. 23. 
kebalikannya dalam sistem ini Presiden juga dapat membubarkan parlemen setiap waktu. ${ }^{7}$

Pada tahun 1955, dimana pemilu pertama kali diselenggarakan, parlemen diwakilil empat partai, yaitu : Masyumi, PNI, NU, dan PKI. Dari keempat partai tersebut, wakil terbanyak berasal dari PNI. ${ }^{8}$ Hal ini sendiri menjadi konsepsi tersendiri pada masa yang dikenal dengan kebebasannya tersebut, atau lebih dikenal dengan nama demokrasi parlementer. Walaupun cukup lama dalam pelaksanaannya, namun pada akhirnya gagasan demokrasi tersebut dianggap gagal, mengingat parlemen tersebut terdiri atas berbagai macam jenis kepartaian sehingga menyulitkan dalam pengambilan keputusannya. Di antara partai partai tersebut, juga mempunyai konsep aliran dalam wadah politiknya, seperti PSII (Partai Sosialis Islam Indonesia), Parkindo (Partai Kristen Indonesia), Partai Katolik, serta Masyumi dan NU yang notabenenya mencirikan diri sebagai partai berbasis massa Islam. ${ }^{9}$

Ketidakberhasilan dari pelaksaan demokrasi parlementer juga terlihat dari seringnya terjadi pergantian kabinet, akibat dari kuatnya serangan dari pihak yang menjadi oposisi. ${ }^{10}$ Adapun pergantian tersebut adalah sebagai berikut:

1. Kabinet Moh Natsir / Masyumi (6 September 1950 - 27 April 1951) atau hanya bertahan selama 233 hari,

7 Yahya A. Muhaimin. Perkembangan Militer Dalam Politik Indonesia 1945-1966.

Yogyakarta: Gadjah Mada University Press ; 1982, hlm. 66-68.

8 Liddle, R. Willam. Pemilu Orde Baru: Pasang Surut Kekuasaan Politik. Yogyakarta : Kelompok Studi Batas Kota ; 1992, hlm. 176.

9 M.C.Ricklefs, Sejarah Indonesia Modern. (Yogyakarta: UGM Press. ; 1991)., hlm.138

10 Ibid., hlm. 135. 
2. Kabinet Sukiman / Masyumi (27 April 1951 - 3 April 1952), atau hanya bertahan selama 341 hari,

3. Kabinet Wilopo / PNI (3 April 1952 - 30 Juli 1953),

4. Kabinet Ali Saastroamidjoyo / PNI (30 Juli 1953-15 Agustus 1955),

5. Kabinet Burhannudin Harahap / Masyumi (12 Agustus 1955- 24 Maret 1956),

6. Kabinet Ali Saastroamidjoyo / PNI (24 Maret 1956- 9 April 1957),

7. Kabinet Juanda / Non partai (9 April 195710 Juli 1959). ${ }^{11}$

Melihat 7 kali pergantian kabinet di atas, pada awalnya Soekarno lebih mempercayakan kepada Masyumi (Natsir dan Sukiman), tentu berharap wajah perpolitikan berkiblat kepada Islam. Namun sayangnya kepercayaan tersebut tidak dapat dimaksimalkan oleh Masyumi, sehingga kepemimpinan beralih kepada PNI. Menurut analisis penulis, walaupun sering dilontarkan oleh Soekarno tentang NASAKOM (Nasionalis, Agama dan Komunis), dalam pelaksanaannya Soekarno tidak pernah memberi porsi kepada Komunis untuk memegang kabinet parlementer.

Walaupun begitu, terdapat satu keberhasilan yang sekiranya dapat dibanggakan pada masa demokrasi parlementer tersebut, yakni berhasil terlaksananya pemilihan umum yang pertama kali pasca Indonesia meraih kemerdekaannya pada tahun 1955, yaitu pada masa kabinet Burhannudin Harahap dari Masyumi. Dari hasil pemilu tersebut, hanya 4 partai yang mendapat kursi lebih dari 8 yaitu; PNI (58 kursi), Masyumi (60 kursi), NU (47 kursi), dan PKI (32 kursi). ${ }^{12}$

Setelahnya, pada masa pemerintahan kabinet Ali Sostroamidjojo, yaitu pada tanggal 26 Maret 1957, DPR kembali melakukan persidangan. Pada pembukaan dalam persidangan tersebut Presiden Soekarno menyampaikan pidatonya mengenainya keinginan akan suatu sistem demokrasi yang benar-benar bercirikan Indonesia atau keindonesiaan. ${ }^{13}$

11 Kisdarto Atmosoeprapto, Pandangan Hidup dan Kepribadian Bung Karno dari A-Z (Kecemerlangan, Kebijakan, dan Kepedulian pada Penderitaan Bangsa). Malang : Bayu Media Publishing.; 2007, hlm. 120

12 Ibid., hlm, 122

13 Ben, Anderson dkk. 100 Tahun Soekarno. Loc. cit., hlm.201. 
Di sisi lain, peristiwa-peristiwa juga turut serta memperkeuh suasana, seperti peristiwa pembatalan hasil sidang dari Konferensi Meja Bundar (KMB) dan pembatalan Uni Indonesia Belanda sepihak oleh Indonesia kala itu terkait dengan persoalan Irian Barat. Hal ini tak pelak membuat kondisi pemerintah Indonesia pada saat itu mengalami keterpurukan, karena pemerintahan yang ada sangat fokus menyoal hal tersebut. Ekses-eksesnya pun segera saja menjadi, seperti yang buruk yakni mulai maraknya pergolakan-pergolakan fisik, baik di pusat maupun di daerah terutama yang terkait dengan permasalahan sosial dan ekonomi, hal ini tentunya menjadi permasalahan sendiri kala itu. ${ }^{14}$

Pergolakan ini berlanjut dengan mencapai puncaknya pada krisis yang berlarut-larut dalam tubuh militer, sehingga menyebabkan runtuhnya sistem politik parlementer. Perubahan sistem ini lebih tegas dilakukan oleh Soekarno melalui Dekrit Presiden yang dikeluarkan pada tanggal 2 Juli 1959, dengan dukungan yang penuh dari pihak militer yang memang kurang cocok dengan demokrasi parlementer. $^{15}$

Pada awal Demokrasi Parlementer, Masyumi masih memegang peranan aktif dalam politik. Pada masa kabinet Natsir dan Kabinet Soekiman, posisi menteri Agama berada ditangan K.H. Wahid Hasyim (tokoh NU dalam Masyumi). Namun penguatan daripada partai Masyumi tersebut tidak bertahan lama akibat pertikaian internal yang terjadi didalamnya. Hal ini mulai terendus pada masa Kabinet Wilopo-Prawoto yang dimulai sejak April 1952, ketika posisi Menteri agama dipegang oleh K.H. Fakih Usman (unsur Muhammadiyah dalam Masyumi). Hal ini membuat basis massa NU menjadi kecewa dan menganggap diri tidak terwakili, sementara unsur Muhammadiyah dalam Masyumi menduduki empat kursi serta PSII sebanyak satu kursi.

Hal ini kemudian membuat NU keluar dari Masyumi dan membuar partai politik baru, ketika pada pertengahan tahun 1953 Kabinet Wilopo digantikan

14 Hering, Bob. Biografi dan Kepribadian Soekarno, Pendiri Republik Indonesia. Dalam Ben, Anderson dkk. 2001. Dalam peringatan 100 Tahun Soekarno. hlm. 187.

15 Ibid., hlm. 187. Baca juga Jurdi Syarifudin. Pemikiran Politik Islam Indonesia. Yogyakarta : Pustaka Pelajar : 2007, hlm. 22. 
dengan Kabinet Ali Sastroamidjojo I, perubahan tersebut juga mewakili NU didalamnya. Hal ini karena NU telah berdiri sendiri sebagai partai politik independen dan mempunyai basis massa yang cukup besar di daerah-daerah, kala itu NU mendapat empat kursi yang meliputi kursi wakil perdana menteri I, menteri dalam negeri, menteri agama, dan menteri agraria. Setelahnya, kabinet Ali I jatuh pada bulan Juli 1945 dan digantikan oleh kabinet Burhanudin Harahap (Masyumi). Kabinet ini merupakan kabinet terakhir sampai partai tersebut bubar pada tahun 1960. Salah satu prestasi dari kabinet ini adalah berhasil menyelenggarakan Pemilu pertama pada tahun $1955 .^{16}$

Sebelum dikeluarkannya Dekrit 5 Juli, pada tanggal 22 April 1959, Soekarno sebagai Presiden pertama RI menyampaikan definisi Demokrasi Terpimpin. Salah satu definisi mengatakan bahwa Demokrasi Terpimpin ialah demokrasi yang dipimpin oleh hikmat kebijaksanaan dalam permusyawaratan/perwakilan. Namun, dalam kesempatan lainnya, Soekarno memberikan penjelasan bahwa yang Ia inginkan bagi Indonesia adalah sebuah konsep demokrasi tanpa ekstrimisme, dalam artian berada di tengah-tengah, tanpa liberalisme yang kebablasan ataupun tanpa diktatorial yang absolut. Demokrasi yang Ia kemukakan adalah sebuah demokrasi kekeluargaan yang dimana demokrasi tersebut berasaskan diri pada musyawarah mufakat yang dikomandoi oleh seseorang pemimpin yang merakyat dan dicintai oleh segenap bangsanya. ${ }^{17}$

Periode Demokrasi Parlementer berakhir setelah dikeluarkannya Dekrit Presiden 5 Juli 1959. Dekrit 5 Juli mengukuhkan kembali UUD 1945 dan pembubaran Majelis Konstituante serta sebagai tanda dimulainya fase baru yang disebut Demokrasi Terpimpin. ${ }^{18}$ Demokrasi yang menjadikan Soekarno sebagai tokoh sentral tersebut bertitik pangkal pada kekecewaannya pada sistem demokrasi yang menurutnya tidak bisa menunjukkan arah yang jelas bagi kesejahteraan masyarakat yang ada kala itu. Di sisi lain, perseteruan politik antara partai yang

16 Panitia Peringatan 100 Tahun Bung Karno, Bung Karno dan Wacana Islam ; Kenangan 100 Tahun Bung Karno, Loc. cit., hlm. 40.

17 Legge, J.D. Soekarno, Biografi Politik. Jakarta : Sinar Harapan ; 1985, hlm. 122.

18 Ahmad Syafi'i Maarif, Islam dan Masyarakat Kenegaraan, Jakarta:LP3ES, 1985, hlm. 40 
satu dengan partai lainnya menurutnya sudah dalam tataran yang tidak sehat sehingga perlu dilakukan perubahan segera. Soekarno pun terlihat jengah dengan adanya konsep demokrasi tersebut, karena sebagai pemimpin, dirinya seakan hanya dianggap simbol dan tidak diurun rembukkan dalam penentuan kebijakan publik dan proses bernegara. Hal ini kemudian membulatkan tekadnya kemudian untuk membentuk sistem demokrasi terpimpin tersebut guna mendapatkan penuh dari rakyat sebagai pemimpin yang revolusioner. Konsep ini pertama kali dirinya strategikan dengan membuat Dewan Nasional pada tanggal 11 Juli 1959 yang diketuai oleh Soekarno sendiri. ${ }^{19}$

Pada tanggal 22 Juli 1959 Dewan Nasional diganti dengan Dewan Pertimbangan Agung Sementara (DPAS) yang juga diketuai oleh Soekarno. Penanganan sehari-hari DPAS diserahkan oleh wakilnya, Roeslan Abdoelgani, tokoh PNI. Dalam perjalanannya kemudian, DPAS ini yang kemudian menjadi kendaraan dan alat bagi Soekarno untuk dapat mengukuhkan pribadinya menjadi pemimpin yang sah dari rakyat dengan mengusulkan agar pidato kenegaraannya tanggal 17 Agustus 1959 dijadikan sebagai Manifesto Politik. Pidato tersebut sendiri berisikan mengenai dasaran-dasaran dari Demokrasi Terpimpin yang dikemukakan oleh Soekano selaku pemimpin besar revolusi. Dasar-dasar tersebut yaitu:

1. Tiap-tiap orang diwajibkan untuk berbakti kepada kepentingan umum, masyarakat, bangsa, dan negara.

2. Tiap-tiap orang berhak mendapat penghidupan layak dalam masyarakat, bangsa, dan negara. ${ }^{20}$

Menurut hemat penulis, peristiwa ini terjadi karena posisi Soekarno pada masa demokrasi parlemter yang dianggap tidak memiliki kekuasaan, Soekarno dalam hal ini hanya sebagai simbol, sementara kekuasaan pemerintahan dipegang sepenuhnya oleh Perdana Menteri. Kondisi inilah yang menjadi dasar pijakan

19 Raharjo, Pamoe dan Islah Gusmian. 2002. Bung Karno dan Pancasila Menuju Revolusi Nasional. Yogyakarta : Galang Press : 2002, hlm. 202.

20 Ricklefs, M.C. Sejarah Indonesia Modern. Loc. cit., hlm. 123-124.. 
pemikiran Soekarno untuk mengembalikan kekuasaan penuh atas dirinya sebagai presiden sebagai pemegang kekuasaan.

\section{Kebijakan Pada Masa Demokrasi Terpimpin}

Demokrasi terpimpin merupakan buah dari kegagalan Demokrasi liberal atau parlementer yang menurut Soekarno malahan membawa Indonesia kepada jurang kenestapaan, baik dalam hal sosial ekonomi, serta politik. Hal ini haruslah ditanggulangi dengan segera dan secepat mungkin, apalagi mulai muncul gerakan-gerakan pergolakan di beberapa daerah, sementara itu di kabinet, para anggota kabinet di konstituante saling baku hantam sehingga gagal melaksanakan tugasnya menyusun UUD yang baru. $^{21}$

Alhasil, selesai lah sudah, puncaknya pada pidato tanggal 22 April 1959 di depan Konstituante dengan judul "Res Publica", Presiden Soekarno atas nama pemerintah menganjurkan, supaya Konstituante dalam rangka rencana pelaksanaan Demokrasi Terpimpin menetapkan UUD 1945 sebagai undang-undang ketatanegaraan yang definitif. ${ }^{22}$

Titik pangkal dari perdebatan dan baku hantam di antara dewan Konstituante itu sebenarnya adalah pada titik perumusan dasar negara. Utamanya pertentangan tersebut berasal dari kelompok pendukung daripada dasar negara Pancasila dan pendukung dasar negara berdasarkan pada syariat Islam. Kelompok Islam sendiri kala itu menganjurkan untuk mengamandemen terma dasaran tersebut dengan memasukkan klausul kata :

21 Dauglas E. Ramage, Percaturan Politik di Indonesia; Demokrasi, Islam, dan Idiologi Toleransi, Terjemahan Hartono Hadikusumo, Loc. cit. hlm. 134.

22 Panitia Peringatan 100 Tahun Bung Karno, Bung Karno dan Wacana Islam ; Kenangan 100 Tahun Bung Karno, Loc. cit., hlm. 45. 
dengan kewajiban menjalankan syariat Islam bagi pemeluk-pemeluknya" ke dalam pembukaan UUD $1945 .^{23}$

Tak pelak, usulan tersebut langsung menimbulkan pro dan kontra serta ditolak oleh sebagian anggota Konstituante dalam sidang tanggal 29 Mei 1959 dengan perbandingan suara 201 yang setuju berbanding 265 yang menolak. Sesuai dengan ketentuan tata tertib maka diadakan pemungutan suara dua kali lagi. Pemungutan suara terakhir dilaksanakan pada 2 Juni 1959 namun tidak mencapai quorum yang diusulkan. Akhirnya Konstituante kala itu sepakat untuk mengadakan reses atau masa istirahat yang ternyata dilakukan dalam jangka waktu tanpa batas. ${ }^{24}$

Dengan memuncaknya krisis nasional dan untuk menjaga eksesekses politik yang mengganggu ketertiban negara, maka KSAD Letjen. A. H Nasution atas nama pemerintah/Penguasa Perang Pusat (Peperpu), pada tanggal 3 Juni 1959 mengeluarkan peraturan No. Prt./ Peperpu/ 040/ 1959 tentang larangan mengadakan kegiatan politik. ${ }^{25}$ Kegagalan Konstituante dalam melaksanakan tugasnya sudah diprediksi sejak semula, terbukti dengan gagalnya usaha kembali ke UUD 1945 melalui saluran konstitusi yang telah disarankan pemerintah. Dengan jaminan dan dukungan dari Angkatan Bersenjata pada saat itu, Presiden Soekarno pada tanggal 5 Juli 1959 lalu mengumumkan Dekrit Presiden dengan mengeluarkan keputusan Presiden R I No. 150 tahun 1959 yang dikenal sebagai Dekrit Presiden 5 Juli 1959, dekrit ini sendiri memuat tiga hal yakni antara lain :

Pertama : Menetapkan pembubaran Konstituante.

23 Edwar Mortimer, Islam dan Kekuasaan, Terjemahan Anna Hadi dan Rahmani Astuti, (Bandung; Mizan ; 1984), hlm. 124.

24 Panitia Peringatan 100 Tahun Bung Karno, Bung Karno dan Wacana Islam ; Kenangan 100 Tahun Bung Karno, Loc. cit., hlm. 40.

25 Dauglas E. Ramage, Percaturan Politik di Indonesia; Demokrasi, Islam, dan Idiologi Toleransi, Terjemahan Hartono Hadikusumo, Loc. cit. hlm. 131. 
Kedua : Menetapkan UUD 45 berlaku lagi bagi segenap Bangsa Indonesia dan seluruh tumpah darah Indonesia, terhitung mulai tanggal penetapan Dekrit ini, dan tidak berlaku lagi UUDS.

Ketiga : Pembentukan MPRS, yang terdiri atas anggotaanggota DPR ditambah dengan utusan-utusan daerah dan golongan, serta pembentukan Dewan Pertimbangan Agung Sementara dalam waktu yang sesingkat-singkatnya. ${ }^{26}$

Demokrasi terpimpin merupakan suatu sistem demokrasi yang dimana berpusat pada seseorang yang dianggap sebagai pemimpin tunggal revolusi. Soekarno, dalam hal ini menjadi titik pusat dan pemimpin dalam periode demokrasi tersebut. Hal ini tentunya membawa konsekuensi politik tersendiri, khususnya bagi umat Islam. Sayap pesantren atau Islam tradisionalis, yaitu NU bersama PSII dan Perti diizinkan hidup di bawah payung Demokrasi terpimpin. Mereka berusaha menyesuaikan diri dengan kondisi politik yang baru dan berusaha bertindak selalu menyenangkan Soekarno. ${ }^{27}$

Di sisi lain, kaum Islam modernis dianggap Soekarno merupakan penghalang bagi terciptanya revolusi. Kaum Islam modernis utamanya Masyumi baginya merupakan musuh bagi sistem demokrasi terpimpin yang Ia ciptakan karena dapat menciptakan instabilitas bagi jargon yang dirinya kemukakan yakni Nasakon (Nasioanalis, Agama, Komunis). Adanya perbedaan antara musuh dan kawan revolusi menyebabkan kristalisasi dalam tubuh umat Islam. Pada tanggal 20 Maret 1960 Soekarno membubarkan parlemen dan menggantinya dengan Dewan Perwakilan Rakyat Gotong Royong (DPR-GR). Dalam hal ini, tokoh-tokoh Masyumi

26 Edwar Mortimer, Islam dan Kekuasaan, Terjemahan Anna Hadi dan Rahmani Astuti, Loc. cit., hlm. 124.

27 Herbert Feith dan Lance Castles. Ed. 1988. "Pengantar", dalam Pemikiran Politik Indonesia 1945-1965, Jakarta: LP3ES , hlm. 132 
dan PSI tidak dimasukan dalam anggota DPR-GR dengan alasan bahwa kedua partai tersebut terlibat dalam pemberontakan. Jika diteliti lebih cermat, keanggotaan DPRGR terdiri dari 94 pihak Nasionalis-Sekuler, kelompok Komunis mendapat 81 kursi, dan wakil Islam hanya mendapat 67 kursi. $^{28}$

Penjelasan umum Penpres Nomor 7 Tahun 1959 menyatakan bahwa Maklumat Pemerintah tanggal 3 November 1945 ternyata tidak berhasil mencapai stabilitas politik. Penjelasan juga menyatakan bahwa ketidakstabilan politik mencapai puncaknya pada waktu Konsituante membicarakan Amanat Presiden tanggal 22 April 1959 yang menganjurkan kembali kepada UUD 1945. Konsituante tidak berhasil mengambil keputusan. Berdasarkan alasan tersebut dipandang telah tiba waktunya untuk mencabut maklumat tersebut serta mengatur perkembangan partai politik sebagai alat demokrasi sehingga dapat berlangsung dalam suasana demokrasi terpimpin. Sebagai pelaksanaan Penpres Nomor 7 Tahun 1959, peraturan selanjutnya yang dikeluarkan untuk melakukan penyederhanaan partai politik adalah Perpres Nomor 13 Tahun 1960 tentang Pengakuan, Pengawasan, dan Pembubaran Partai Politik yang selanjutnya diubah dengan Perpes Nomor 25 Tahun 1960. Perpes Nomor 13 Tahun 1960 mewajibkan kepada partai politik yang telah berdiri pada 5 Juli 1959 untuk menyesuaikan AD dan ART dengan ketentuan dalam Penpres Nomor 7 Tahun $1959 .{ }^{29}$

Sebagai pelaksanaan dari Perpes Nomor 13 Tahun 1960, pada 14 April 1961 dikeluarkan Kepres Nomor 128 Tahun 1961 yang mengakui 8

28 Ibid., hlm. 133. Baca juga Nurdin M. Amin.. Sejarah Pemikiran Islam. (Bandung : Amazah , 2010)., hlm. 32.

${ }_{29}$ Muchamad Ali Safa'at, Pembubaran Partai Politik, Pengaturan dan Praktik Pembubaran Partai Politik dalam Pergulatan Republik. Jakarta : Rajawali Pers ; 2011, hlm. 160. 
partai politik, yaitu PNI, NU, PKI, Partai Katolik, Partai Indonesia (Partindo), Partai Murba, PSI Arudji, dan IPKI. Pada hari yang sama juga dikeluarkan Keppres Nomor 129 Tahun 1961 yang menolak mengakui 4 partai politik, yaitu PSI Abikusno, PRN Bebasa, PRI, dan PRN Djody. ${ }^{30}$

Selain itu, pada 27 Juli 1961 dikeluarkan Keppres Nomor 440 Tahun 1961 yang mengakui Parkindo dan Persatuan Tarbiyah Islam (Perti). ${ }^{31}$ Terhadap Keputusan Presiden yang tidak mengakui beberapa partai politik tersebut tidak terdapat upaya hukum yang diajukan ke pengadilan. Kala itu tidak yang dapat menandingi kekuasaan Soekarno yang sangat besar, bahkan Ketua MA ditempatkan sebagai Menteri Koordinator Hukum dan Dalam Negeri, sehingga kedudukannya berada di bawah Presiden, akibat dari kebijakan Soekarno yang melakukan penyederhanaan kepartaian tersebut, maka partai-partai yang ada kala itu menjadi tidak efektif dan terkesan hanya menjadi alat kekuasaan daripada rezim yang berkuasa kala itu. Belum lagi tekanan-tekanan dari penguasa yang menandaskan bahwa partai-partai politik yang ada harus sesuai dengan manifesto politik presiden Soekarno, dan apabila tidak konsekuensinya adalah tidak akuinya partai tersebut dalam sistem demokrasi di Indonesia. Nahasanya, partai-partai tersebut juga tidak dapat melakukan upaya hukum atas tidak di akuinya partai-partai tersebut oleh penguasa pada masa tersebut. Dari 4 partai yang tidak diakui itu misalnya, terdapat Partai Rakyat Indonesia (PRI) yang menurut hasil pemilu 1955 memperoleh 2 kursi di DPR. PRI tidak mendapatkan kursi dalam DPRGR yang dibentuk

\footnotetext{
30 Ibid., hlm. 165.
}

31 Edward Mortimer, Islam dan Kekuasaan, Terjemahan Anna Hadi dan Rahmani Astuti, Loc. cit., hlm. 124. 
berdasarkan Penpres Nomor 4 Tahun 1960. Sedangkan partai-partai yang diakui mendapatkan jatah kursi, kecuali IPKI. ${ }^{32}$

Sejak tahun 1960 Soekarno yang terus menerus melakukan propaganda terhadap demokrasi terpimpin yang dijalankannya mulai mendapatkan banyak respon dari masyarakat yang lambat laun mulai merasakan belenggu dan pola yang represif akibat sistem yang dijalankan oleh presiden Soekarno tersebut. ${ }^{33}$ Dalam konsep politik misalnya, di sini umat Islam kehilangan kursi sebanyak 48 jika dibandingkan dengan parlemen sebelumnya. Hal ini bukan apa-apa dibandingkan kerugian yang diterima oleh kalangan Islam modernis yang dicap sebagai musuh revolusi oleh Soekarno. ${ }^{34}$ Kala itu Soekarno juga menyampaikan pemikirannya mengenai ideologi Demokrasi Terpimpin yang Ia namakan sebagai Manifesto Politik (Manipol). Melalui hal tersebut, Ia mengemukakan pelbagai hal seperti keadilan sosial, kebudayaan Indonesia, semangat revolusioner, sampai kepada revitalisasi daripada kelembagaan negara demi menjunjung semangat revolusi Indonesia agar tidak padam. Pada awal tahun 1960 ideologi yang samar-samar ini menjadi semakin rumit dengan ditambahkannya kata USDEK (Undang-Undang Dasar 1945, Sosialisme ala Indonesia, Demokrasi Terpimpin, Ekonomi Terpimpin, dan Kepribadian Indonesia). Soekarno mengharuskan pers mendukung Manipol-USDEK yang dicetuskannya. Namun, beberapa redaktur yang pro-Masyumi dan proPSI menolak sikap mendukung terhadap Manipol-USDEK. Sebagai

32 Edwar Mortimer, Islam dan Kekuasaan, Terjemahan Anna Hadi dan Rahmani Astuti, Bandung ; Mizan ; 1984, hlm. 162.

33 John D Legge, Soekarno Sebuah Biografi Politik. (Jakarta : Sinar Harapan ; 1985), hlm. 368.

34 Ibid, hlm.183-186 
akibatnya, terjadi pembredelan surat kabar yang kontra terhadap kebijakan Soekarno tersebut. ${ }^{35}$

Semakin lama, kebijakan-kebijakan yang dilakukan oleh Soekarno makin mendekatkan diri pada pola Nasakom (Nasionalis, Agama, Komunis). Perwujudan dari politik Nasakom ini adalah tampilnya PNI sebagai wakil Nasionalis, NU sebagai wakil Agama, dan PKI sebagai wakil Komunis dalam koalisi kabinet baru bentukan Soekarno. ${ }^{36}$ Bentuk Demokrasi Terpimpin yang dipilih oleh Soekarno setidaknya telah mempersempit gerak umat Islam dalam panggung politik Indonesia. Ketidakpuasan Soekarno yang hanya sebagai presiden simbol sebagaimana ditetapkan dalam UUDS 1950 sebagai landasan konstitusional pelaksanaan Demokrasi Parlementer, menyebabkan Soekarno menetapkan Demokrasi Terpimpin sebagai solusi bagi hal tersebut.

Keinginan Soekarno untuk berkuasa secara langsung disampaikan pertama kali pada tanggal 28 Oktober 1956 pada waktu ia mengemukakan konsepsi Bung Karno. Perpindahan politik ini dianggap oleh sebagian orang telah menyimpang dari UUDS 1950. Di antara reaksi terhadap move politik Soekarno dilontarkan oleh Isa Anshory, anggota DPR. Menurutnya, konsepsi Bung karno memungkinkan terbentuknya demokrasi tanpa oposisi. $^{37}$

Umat Islam sendiri memiliki pandangan yang berbeda terhadap demokrasi terpimpin. Pada garis besarnya, umat Islam terbagi menjadi dua golongan yaitu golongan yang kontra dan golongan yang ikut tergabung dalam Demokrasi Terpimpin. Masyumi sebagai golongan yang menentang

35 M.C.Ricklefs, Sejarah Indonesia Modern, Terj.Dharmono Hardjowidjono Yogyakarta : Gajah Mada University Press, 1994. hlm.403-404

36 Ibid,. hlm.406

37 Maarif, Islam dan Politik Indonesia pada Masa Demokrasi Terpimpin (1959-1965), Loc. cit., hlm. 52 
model politik Soekarno memandang bahwa Demokrasi Terpimpin merupakan sistem demokrasi yang otoriter, yang menyimpang dari ajaran Islam. Oleh sebab itu, Masyumi tidak mau terlibat dalam politik Soekarno. Kelompok kedua yaitu kelompok Liga Muslim (NU, PSII, dan Perti) yang turut serta dalam Demokrasi Terpimpin. Keterlibatan mereka dalam politik Demokrasi Terpimpin merupakan sebuah sikap yang realistik dan pragmatik. Saifudin Zuhri sebagai wakil dari NU, misalnya, membawakan dalil "Apa yang tidak bisa diraih secara utuh maka sebagian yang lain jangan dilepaskan" untuk membenarkan keterlibatan NU dalam Demokrasi Terpimpin. ${ }^{38}$ Berdasarkan dalil yang diajarkan di pesantren inilah NU turut masuk dalam Demokrasi Terpimpin. ${ }^{39}$

Berbeda halnya dengan Masyumi dan kalangan Islamis modern lainnya yang menganggap bahwa apa yang telah Soekarno perbuat, terutama keterlibatannya dengan PKI yang notabenenya berhaluan komunisme sebagai hal yang tidak bisa ditolerir. Hal ini kemudian yang membuat Masyumi kala itu, dan Partai Sosialis Indonesia (PSI) yang juga memandang kebijakan Soekarno sebagai hal yang keliru mulai melancarkan sikap kontranya kepada Soekarno. Hal ini kemudian direalisasikan pada bulan Maret 1960, dimana Masyumi dan PSI kala itu menolak anggaran belanja pemerintah yang diajukan pada rapat DPR yang terpilih tahun 1955 (lembaga terakhir di mana mereka terwakili). ${ }^{40}$

Di sisi lain, atas inisiatif yang dilakukan oleh Hatta dan beberapa tokoh militer, PSI, Masyumi dan beberapa sekutunya membentuk Liga

38 Edwar Mortimer, Islam dan Kekuasaan, Terjemahan Anna Hadi dan Rahmani Astuti, Loc. Cit., hlm. 157

39 Dauglas E. Ramage, Percaturan Politik di Indonesia; Demokrasi, Islam, dan Idiologi Toleransi, Terjemahan Hartono Hadikusumo, Loc. Cit., hlm. 140.

40 Panitia Peringatan 100 Tahun Bung Karno, Bung Karno dan Wacana Islam ; Kenangan 100 Tahun Bung Karno, Loc. cit., hlm. 51. 
Demokrasi sebagai tandingan Demokrasi Terpimpin. ${ }^{41}$ Liga Demokrasi dibentuk pada tanggal 24 Maret 1960 yang beranggotakan beberapa tokoh dari partai Masyumi, PSI, serta tokoh-tokoh lain dari unsur Parkindo, IPKI, dan bahkan juga dari NU. Dalam hal ini, tokoh NU yang turut serta dalam Liga Demokrasi tersebut ialah K.H. M. Dahlan dan Imron Rosjadi, walaupun secara garis kepartaian, sebagian besar atau pada umumnya kelembagaan NU mendukung terlaksananya demokrasi terpimpin yang dicetuskan oleh Soekarno. ${ }^{42}$

Liga Demokrasi ini sendiri dibuat sebagai dasaran perlawanan terhadap sikap otoritarian Soekarno yang membubarkan DPR hasil pilihan rakyat pada pemilu tahun 1955. Terbentuknya Liga Demokrasi ini sendiri baru diketahui Soekarno kemudian, mengingat pada saat pada saat Liga didirikan, Soekarno kala itu sedang melakukan lawatan ke luar negeri. Setelah Ia kembali ke tanah air dan mengetahui hal tersebut, Soekarno langsung memberikan arahannya untuk membubarkan kelembagaan tersebut. Tak pelak sesuai arahan Soekarno, beberapa bulan setelahnya Liga ini dibubarkan tanpa adanya perlawanan sama sekali. Setelah pembubaran Liga Demokrasi, maka tidak ada yang kemudian dapat menghentikan Soekarno dengan segala ide-idenya mengenai revolusi Indonesia dan demokrasi terpimpin. Hal ini kemudian juga ditambah dengan dukungandukungan kepartaian yang pro terhadap kebijakan daripada Soekarno sehingga Ia mengiar bahwa sistem yang diciptakannya sudah berjalan dengan baik dan mulus. Apabila kita menilik lebih dalam, maka demokrasi yang diperjuangkan mati-matian oleh Masyumi dan PSI kala itu dengan membuat Liga Demokrasi pada akhirnya hanya menjadi sekedar gejala urban saja, mengingat kedua partai ini bercorak kota, terutama PSI.

41 Ricklefs, Sejarah Indonesia Modern. Terj.Dharmono Hardjowidjono. Loc. cit.. hlm 405

42 Edward Mortimer, Islam dan Kekuasaan, Terjemahan Anna Hadi dan Rahmani Astuti, Loc. cit, hlm. 146. 
Masyumi, sekalipun memiliki pengikut di daerah pedesaan, partai ini adalah partai kota karena partai ini mewakili kaum modernis muslim. Berbeda dengan NU yang mewakili Islam santri pedesaan. ${ }^{43}$

Kekecewaan Masyumi terhadap pemerintahan Soekarno juga terletak pada putusan Soekarno membentuk DPR-GR. Hal ini tentunya beralasan, mengingat akhirnya partai sebesar Masyumi tidak mendapatkan wakilnya didalam parlemen kala itu. Sebuah artikel dalam majalah Hikmah yang merupakan milik Masyumi mencerminkan sikap kekecewaan mereka juga kepada pihak NU yang telah bergabung dengan Demokrasi Terpimpin. $^{44}$

Pada tangal 20 Januari 1961 dibentuk Front Nasional yang sesuai dengan konsep dan ide Soekarno. Hal ini sendiri merupakan ide jangka panjang dari Soekarno yang menginginkan adanya suatu partai tunggal yang besar dengan corak dari bermacam ideologi serta berunsur dari berbagai golongan-golongan fungsional. Sistem penggeraknya adalah massa rakyat, yang apabila kita tilik ada kemiripan dengan sistem satu partai yang biasa dijalankan oleh negara-negara yang berhaluan komunisme. Hal ini sendiri mendapatkan respon yang cepat, utamanya dari pihak-pihak yang kontra terhadap PKI, seperti salah satunya adalah militer yang dalam hal ini ialah TNI-AD. Guna menghambat rencana Soekarno tersebut, TNI-AD berhasil menghimpun beberapa organisasi golongan fungsional kedalam suatu organisasi yang bernama Sekber (Sekretariat Bersama) pada tanggal 20 Oktober 1964. Tujuan Sekber untuk menandingi kekuatan PKI yang

43 Syafi'i Maarif, Islam dan Politik Indonesia pada Masa Demokrasi Terpimpin (19591965). Loc. cit..hlm. 64-65

44 Syafi'i Maarif, Islam dan Masyarakat Kenegaraan, Loc. cit. hlm. 187 
semakin besar dan berpengaruh di masyarakat sehingga membahayakan eksistensi TNI. ${ }^{45}$

Dari keterangan di atas dapat disimpulkan bahwa masa Demokrasi Terpimpin mempunyai ciri-ciri, yaitu pertama, peran dominan Presiden dalam segala aspek. Kedua pembatasan atas peran DPR serta partai-partai politik kecuali PKI yang malahan mendapat kesempatan untuk berkembang. Ketiga, peningkatan peran TNI sebagai kekuatan sosial politik. ${ }^{46}$

Ada beberapa kejadian penting pada masa demokrasi terpimpin yang sangant mencolok menguntungkan Angkatan Darat, antara lain:

1. Pada tahun 1945-1950. Diberlakukanlah sistem demokrasi parlementer, yang dimana pada saat itu guna kemaslahatan rakyat, Soekarno merelakan tampuk kepemimpinannya sebagai seorang kepala negara atau presiden. Dimana pada saat itu kekuasaan pemerintahan dipegang oleh Perdana Menteri dan Presiden hanya sebagai simbol dari Kepala Negara.

2. Peristiwa 17 Oktober 1952: Pada peristiwa ini militer secara terbuka menuntut agar parlemen dibubarkan karena dianggap tidak efektif dalam melakukan penyelenggaraan pemerintahan. Hal ini sendiri ditentang oleh Soekarno yang masih setia dengan konstitusi yang ada pada saat itu.

3. Pemberontakan PRRI/Permesta, pemberlakuan SOB, keadaan darurat perang, peristiwa Irian Barat, merupakan peristiwa-peristiwa dimana pada saat itu pihak angkatan darat mulai mengambil peranan terhadap pelbagai pemberontakan tersebut

4. Nasionalisasi Perusahaan-perusahaan raksasa Belanda (The Big Five). Peristiwa ini merupakan titik pangkal dimana militer, terutama TNI-AD kala itu mulai memasuki kancah bisnis, dimana pada saat itu beberapa petinggi di TNI didapuk untuk menjadi direktur-direktur dilembaga tersebut. Di sisi lain,

45 Miriam Budiardjo,1996. Demokrasi di Indonesia Demokrasi Parlementer dan Demokrasi Pancasila. Jakarta: Gramedia Pustaka Utama; 1995, hlm. 228.

46 Mohammad Mahfud MD, Demokrasi dan Konstitusi di Indonesia. Jakarta: Penerbit Rineka Cipta ; 2000, hlm.229. 
hal ini merupakan pintu masuk dari bisnis tentara, dari yang awalnya di bidang niaga, lalu kemudian meningkat di bidang-bidang lain, seperti industri, dan bahkan ladang minyak. ${ }^{47}$

5. Dekrit Presiden 5 Juli 1959 dengan Angkatan Darat yang menjadi motor dan sekaligus sebagai pendukung utama. Dengan demikian, maka kesempatan pun terbuka lebar bagi Angkatan Darat untuk melansir demokrasi menurut konsep mereka. Tidak pula dapat dilupakan bahwa pengangkatan Soekarno sebagai presiden seumur hidup oleh Soksi sebagai komponen kekuasaan Angkatan Darat. Akan tetapi sesudah 1965 beredar berita bahwa semua kejadian tersebut adalah impementasi dari ambisi Soekarno yang haus kekuasaan dengan dukungan PKI. ${ }^{48}$

6. Konfrontasi dengan Malaysia juga merupakan kesempatana emas bagi angkatan darat untuk mengontrol seluruh negeri lewat konsep penguasaan teritorial, untuk lebih leluasa lagi memegang anggaran belanja negara dan memegang mandate-blanko guna mengadakan pembelian senjata secara besar-besaran. $^{49}$

Kesemua kronologi tersebut pada akhirnya bersimpul pada konsep dimana tentara mulai menguasai dari apa yang sebelumnya Soekarno telah tanam. Titik puncaknya pada akhirnya terjadi pada peristiwa G-30-S, dimana Presiden Soekarno kala itu berbicara menentang kejadian yang merupakan "epilog" dari insiden gerakan yang dituding dilakukan oleh para tokoh PKI tersebut. "Epilog ini" katanya, "telah mengganggu sukmaku, telah membuatku sedih, membuatku khawatir.....Dengan terus terang kukatakan aku meratap kepada Allah, bertanya kepada Tuhan, bagaimana

47 Ibid., hlm. 230. Baca juga Adian Husaini, Indonesia Masa Depan Perspektif Peradaban Islam, Orasi Ilmiah dalam acara Tasyakur gelar "Doktor" Adaian Husaini oleh INSISTS di Aula Masjid Al-Furqan Dewan Da'wah, 18 April 2009. hlm. 33

48 Ibid., hlm. 231. Baca juga Arief Furchan dan Agus Maimun, Studi Tokoh, Metode Penelitian Tokoh, Yogyakarta: Pustaka Pelajar, 2005, hlm., 16.

49 Atmosoeprapto, Kisdarto. Pandangan Hidup dan Kepribadian Bung Karno dari A-Z (Kecemerlangan, Kebijakan, dan Kepedulian pada Penderitaan Bangsa). Malang : Bayu Media Publishing ; 2007, hlm. 207 
ya Allah, Robbi, bagaimana semua ini dapat terjadi?" Hal ini menyatakan secara jelas bahwa Soekarno benar-benar merasa bersedih dan prihatin mengenai peristiwa pembunuhan para Jenderal tersebut, walaupun disisi lain, dirinya tentunya sepenuhnya sadar akan konsekuensi politik yang akan berpengaruh terhadap dirinya pasca peristiwa G30S terjadi. ${ }^{50}$

Menurut hemat penulis, perubahan dari sistem pemerintahan demokrasi parlementer menjadi demokrasi terpimpin adalah wujud keberhasilan Soekarno dalam mengembalikan kekuasaan dirinya sebagai presiden. Soekarno menggandeng partai-partai politik yang mendukung idenya dan bahkan mereka mendapatkan posisi dan jabatan strategis serta Soekarno membumihanguskan partai-partai penentangnya. Konsepnya terbungkus dengan gagasan "NASAKOM", yakni partai nasional, Agama (diwakili NU, PERTI dan PSII), dan Komunis.

\section{Sikap Soekarno Terhadap Masyumi}

Dalam konsep politiknya, Soekarno melihat partai Masyumi sebagai sebuah penghalang besar bagi terselenggaranya Demokrasi Terpimpin mengingat akan kekuatan besarnya yang telah mengakar sejak masa Kemerdekaan. Sampai pada awal tahun 1950 partai Masyumi masih merupakan kekuatan yang sangat kuar mendominasi parlemen, hal ini terbukti setelah Soekarno pernah menunjuk wakil dari Masyumi untuk menjadi formateur kabinet sebanyak dua kali secara berurutan. Di sisi lain, peristiwa penyerahan formateur kepada Masyumi bisa jadi merupakan strategi politik kala itu untuk memecah kekuatan didalam tubuh Masyumi yang notabenenya merupakan partai keagamaan Islam terbesar. Seperti ketika Soekarno sebagai presiden kala itu memilih Sukiman sebagai

50 Harold Crouch, Militer dan Politik di Indonesia . (Jakarta : LP3ES ; 1986), hlm. 151. Baca juga Onghokham, Soekarno. Orang Kiri, Revolusi \& G30S 1965. (Jakarta : Komunitas Bambu ; 2009), hlm.178. 
formatur tanpa meminta pesetujuan Natsir sebagai ketua eksekutif Masyumi. Tindakan Sukiman tetap melaksanakan tugas sebagai formatur tanpa persetujuan eksekutif partai Masyumi tersebut dianggap sebagai tindakan indispliner dalam kepartaian. Peristiwa ini menunjukkan bahwa dalam tubuh Masyumi sendiri terdiri dari kelompok-kelompok. ${ }^{51}$ Pada saat pemerintahan berada dibawah kepemimpinan Masyumi itulah Soekarno kemudian melihat celah yang dapat dimanfaatkan, yakni adanya pertarungan internal didalam tubuh kepartaiannya, yang lazim kala itu terjadi diantara Muhammadiyah dan Nadhlatul Ulama, dimana keduanya merupakan basis massa terbesar dari partai tersebut. ${ }^{52}$

Dalam kongres Masyumi yang berlangsung pada akhir tahun 1949 terjadi perombakan kedudukan Majelis Syura', yang berisi para kyai atau ulama, yang sebelumnya merupakan majlis yang memiliki pengaruh besar terhadap kebijakan Masyumi menjadi setingkat dengan badan penasehat saja. Dengan adanya perubahan struktur tersebut maka ulama dari kalangan NU merasa posisinya tergeser sebab arahan kerja dari badan yang terbentuk selanjutnya tersebut kurang mampu mempengaruhi kebijakan partai. Keresahan NU semakin memuncak ketika beredar isu bahwa jabatan Menteri Agama akan diserahkan kepada Muhammadiyah. KH. Wahab Hasbullah, Rais 'Am Majlis Syuriah NU, menuntut agar kursi menteri agama tetap diserahkan kepada NU. Tuntutan KH. Wahab Hasbullah antara lain adalah agar perdana menteri tetap dipercayakan kepada Sukiman,

51 Reaksi Natsir atas peristiwa tersebut digambarkan oleh Herbert Feith sebagai berikut : “ Hanya beberapa jam sebelum formatur menyampaikan susunan kabinet kepada Presiden, Dewan Eksekutif Masyumi (Pimpinan Natsir) mengeluarkan pendapat bahwa tindakan Sukiman sebagai formateur tidak atas nama Masyumi ". Lihat Cosmas Batubara. Sejarah Lahirnya Orde Baru, Hasil dan Tantangannya. (Yayasan Prahita ; Jakarta ; 1986). hlm. 4.

52 Dauglas E. Ramage, Percaturan Politik di Indonesia; Demokrasi, Islam, dan Idiologi Toleransi, Terjemahan Hartono Hadikusumo, Loc. cit. hlm. 138. 
sedangkan Abu Hanifah dicalonkan sebagai Menteri Luar Negeri, Zainul Arifin sebagi Menteri pertahanan, dan Wachid Hasyim menduduki jabatan sebagai menteri agama. Tuntutan NU tersebut jelas menggoyahkan kedudukan formatur Sidik dan Prawoto yang telah berhasil menyelesaikan penyusunan programnya. ${ }^{53}$

Sementara itu dari kalangan Muhammadiyah juga telah mengajukan Fakih Usman sebagi menteri agama dan pada giliran selanjutnya organisasi massa ini menolak secara tegas tuntutan NU. Alasan Muhammadiyah menolak usulan KH Wahab Hasbullah disebabkan NU telah memegang jabatan kementrian agama selama tiga kali berturut-turut, maka perlu adanya pergantian kepemimpinan mengingat Muhammadiyah juga merupakan organisasi massa Islam yang mempunyai pengikut yang tidak sedikit sehingga membutuhkan penyegaran kembali. Argumentasi Muhammadiyah tersebut ditampik balik oleh NU dengan menyatakan bahwa penyegaran kabinet hanya akan menghambat upaya penanaman pengaruh dan dakwah Islam dalam birokrasi kementrian agama. Alasan sebenarnya NU mengatakan hal tersebut antara lain ialah karena pada saat itu NU merasa bahwa jika kementrian Agama jatuh ke tangan Muhammadiyah, maka massa NU yang cukup besar menyokong Masyumi hanya akan menjadi 'sapi perah' bagi kekuasaan yang didominasi oleh orang-orang Muhammadiyah. Maka kemudian KH. Wahab Hasbullah juga mengajukan calon lain untuk menduduki jabatan sebagi Menteri Agama yaitu KH. Masykur, KH. Faturrachman, H. Mustari, dan M. Machien. ${ }^{54}$

53 Panitia Peringatan 100 Tahun Bung Karno, Bung Karno dan Wacana Islam ; Kenangan 100 Tahun Bung Karno, Loc. cit., hlm. 50.

54 Kemungkinan besar hal ini diakibatkan calon sebelumnya yang diajukan oleh KH. Wahab Hasbullah, yaitu KH. Wahid Hasyim, pernah tersandung dengan kasus kegagalan pemberangkatan haji akibat korupsi dalam tubuh Kementerian Agama. Korupsi tersebut 
Walaupun begitu, pada akhirnya berdasarkan kesepakatan terakhir, kementrian agama akhirnya tetap jatuh ketangan Muhammadiyah. Hal ini tentunya menimbulkan kekecewaan yang amat dalam di dalam tubuh NU sehingga pada giliran selanjutnya terbetik isu keluarnya NU dari tubuh Masyumi. Sampai kemudian dalam kongres ke 19 NU, hal ini direalisasikannya secara nyata dengan keluarnya keputusan NU untuk tidak ikut lagi didalam tubuh kepartaian Masyumi. ${ }^{55}$

Selain persoalan perseteruan internal di tubuh Masyumi, PKI disisi lain juga berstrategi dengan merumuskan strategi baru perjuangannya untuk "meng-Indonesiakan Marxisme-Leninisme" dengan menempuh taktik kalsi berupa "front persatuan nasional" yaitu bekerja sama dengan golongangolongan non-komunis dan mendukung kabinet nasional walaupun dianggap sebagai "borjuasi nasional". ${ }^{56}$ Strategi ini sendiri mirip jika tidak dapat dikatakan mengadopsi strategi terbaru Uni Sovyet yang berusaha menggandeng Negara-negara yang baru merdeka di Asia, ${ }^{57}$ guna mensukseskan agenda penyebaran paham negaranya. Untuk menghadapi

sebenarnya merupakan kesalahan dalam sistem kabinet parlementer, namun sebagai menteri agama yang mengurusi keberangkatan haji beliau ikut tersangkut dengan perkara tersebut.

55 Lihat Pusat Sejarah dan tradisi ABRI. Bahaya Laten Komunisme di Indonesia . Jilid III. (Markas Besar angkatan Bersenjata Republik Indonesia Pusat Sejarah ABRI, Jakarta, 1995). hlm. 39

56 Deliar Noer. Gerakan Moderen Islam di Indonesia 1900-1942, (Jakarta : LP3ES ; 1982), hlm. 140 .

57 D. Soegondo. Komunisme di Indonesia. (Lembaga Pertahanan Nasional, Jakarta, 1981). hlm . 20. 
Pemilu 1955, PKI bahkan bersedia menggandeng Partai NU yang merupakan pecahan dari Masyumi. ${ }^{58}$

Langkah awal yang dilakukan oleh PKI tersebut terkait dengan agenda politiknya untuk mencegah kemungkinan adanya kerjasama antara Masyumi (dan pecahannya) dengan PNI. Maka kemudian PKI mengeluarkan pendapatnya bahwa Masyumi merupakan golongan borjuis besar yang melayani kepentingan kapitalis luar negeri dan mengemukakan adanya hubungan yang erat antara Masyumi dengan gerakan Darul Islam di Jawa Barat, Jawa Tengah, Sulawesi Selatan, dan Aceh. ${ }^{59}$

Hal ini kemudian terealisasi di dalam kancah politik yang ada kala itu, dimana PNI, yang pada saat itu di bawah kepemimpinan Sidik Djojosukarto termakan oleh isu tersebut dan pada akhirnya lebih memilih untuk bekerja sama dengan PKI dibandingkan dengan Masyumi. Hal ini sendiri dapat dimaklumi, mengingat Masyumi merupakan salah satu rival kontestan yang kuat bagi PNI dalam Pemilu 1955, dan disisi lain pengaruh Masyumi yang islamis modern agak sulit untuk dapat bercampur dengan PNI dan PKI yang notabenenya merupakan nasionalis dan komunisme yang netral agama. Masyumi yang kala itu sudah mendapatkan lawan yang besar, yakni PNI dan PKI, juga pada akhirnya tidak bisa berbuat banyak akibat pertikaian internal dimana salah satu unsur pendukung terbesarnya, yaitu NU memilih untuk keluar dari unsur kelembagaan Masyumi tersebut. ${ }^{60}$

58 Pusat Sejarah dan Tradisi ABRI. Ibid. Hlm. 42. Adian Husaini, Indonesia Masa Depan Perspektif Peradaban Islam, Orasi Ilmiah dalam acara Tasyakur gelar "Doktor" Adaian Husaini oleh INSISTS di Aula Masjid Al-Furqan Dewan Da'wah, 18 April 2009. hlm. 33

59 Ibid., hlm. 43. Dwi Purwoko Dwi Purwoko et. all., Negara Islam, (Depok: PT. Permata Artistika Kreasi, 2001)., hlm. 82

60 Umaruddin Masdar dkk, Partai Advokasi; Wacana, Keberpihakan dan Gerakan, cet ke-I (Jogjakarta; KLIK-R, 2004), hlm. 55. 
Menurut hemat penulis, Soekarno alergi dengan gagasan dan gugatan oleh tokoh-tokoh Masyumi yang diwakili M. Natsir dan Sukiman yang mengancam posisi dan kedudukannya sebagai presiden. Kekhawatirannya ini yang membuat ia membekukan Masyumi. 


\section{DAFTAR PUSTAKA}

Adian Husaini, 2009, Indonesia Masa Depan Perspektif Peradaban Islam, Orasi Ilmiah dalam acara Tasyakur gelar "Doktor" Adaian Husaini oleh INSISTS di Aula Masjid Al-Furqan Dewan Da'wah,

Atmosoeprapto, Kisdarto. 2007, Pandangan Hidup dan Kepribadian Bung Karno dari A-Z (Kecemerlangan, Kebijakan, dan Kepedulian pada Penderitaan Bangsa). Malang : Bayu Media Publishing

A. Muhaimin. Yahya. 1982, Perkembangan Militer Dalam Politik Indonesia 1945-1966. Yogyakarta: Gadjah Mada University Press

Batubara. Cosmas. 1986, Sejarah Lahirnya Orde Baru, Hasil dan Tantangannya. Yayasan Prahita ; Jakarta

Budiardjo, Miriam. 1996. Demokrasi di Indonesia Demokrasi Parlementer dan Demokrasi Pancasila. Jakarta: Gramedia Pustaka Utama

Crouch, Harold. 2009, Militer dan Politik di Indonesia . Jakarta : LP3ES

Furchan, Arief, dan Agus Maimun, 2005, Studi Tokoh, Metode Penelitian Tokoh, Yogyakarta: Pustaka Pelajar,

Herbert Feith, 1962, The Decline of Constitutional Democracy in Indonesia (1962),

Herbert Feith dan Lance Castles. 1988, Ed. Pemikiran Politik Indonesia 1945-1965, Jakarta : LP3ES

Hering, Bob. 2001., Biografi dan Kepribadian Soekarno, Pendiri Republik Indonesia. Dalam Ben, Anderson dkk. 2001. Dalam peringatan 100 Tahun Soekarno

John D Legge, 1985, Soekarno Sebuah Biografi Politik. Jakarta : Sinar Harapan

Legge, J.D. 1995, Soekarno, Biografi Politik. Jakarta : Sinar Harapan 
Liddle, R. Willam. 1992, Pemilu Orde Baru: Pasang Surut Kekuasaan Politik. Yogyakarta : Kelompok Studi Batas Kota

Mahfud MD, Mohammad, 2000, Demokrasi dan Konstitusi di Indonesia. Jakarta: Penerbit Rineka Cipta

Masdar, Umaruddin dkk, 2004, Partai Advokasi; Wacana, Keberpihakan dan Gerakan, cet ke-I., Jogjakarta; KLIK-R

Mortimer, Edwar, 1984, Islam dan Kekuasaan, Terjemahan Anna Hadi dan Rahmani Astuti, Bandung ; Mizan

Muchamad Ali Safa"at, 2011 Pembubaran Partai Politik, Pengaturan dan Praktik Pembubaran Partai Politik dalam Pergulatan Republik. Jakarta : Rajawali Pers

Noer. Deliar, 1982, Gerakan Moderen Islam di Indonesia 1900-1942, Jakarta : LP3ES.

Nurdin M. Amin.. 2010, Sejarah Pemikiran Islam. Bandung : Amazah

Onghokham, 2009, Soekarno. Orang Kiri, Revolusi \& G30S 1965. Jakarta : Komunitas Bambu

Purwoko, Dwi., et. all.,2001, Negara Islam, Depok: PT. Permata Artistika Kreasi, 2001

Pusat Sejarah dan tradisi ABRI. 1995, Bahaya Laten Komunisme di Indonesia. Jilid III. (Markas Besar angkatan Bersenjata Republik Indonesia Pusat Sejarah ABRI, Jakarta,

Raharjo, Pamoe dan Islah Gusmian. 2002. Bung Karno dan Pancasila Menuju Revolusi Nasional. Yogyakarta : Galang Press

Ricklefs, M.C, 1994, Sejarah Indonesia Modern, Terj. Dharmono Hardjowidjono Yogyakarta:Gajah Mada University Press,

Saifuddin Anshari,. Endang 1986, Piagam Jakarta 22 Juni 1945 ; dan Sejarah Konsesnsus Nasional Antara Nasionalis Islam dan Nasionalis Sekuler Tentang Dasar Negara RI 1945-1959, Jakarta : CV Rajawali Press ; 
Soegondo. D., 1981, Komunisme di Indonesia. Lembaga Pertahanan Nasional, Jakarta,

Soekarno. 1964. "Nasionalisme, Islamisme dan Marxisme", dalam Dibawah Bendera Revolusi, Jakarta: Departemen Penerangan.

Syarifudin. Jurdi 2007, Pemikiran Politik Islam Indonesia. Yogyakarta : Pustaka Pelajar

Syafi'i Maarif, Ahmad, 1985, Islam dan Masyarakat Kenegaraan, Jakarta : LP3ES, 